\title{
Seasonal variation in body weight: an experimental case study
}

Citation for published version (APA):

Westerterp, K. R. (2001). Seasonal variation in body weight: an experimental case study. Journal of Thermal Biology, 26, 525-527. https://doi.org/10.1016/S0306-4565(01)00073-0

Document status and date:

Published: 01/01/2001

DOI:

10.1016/S0306-4565(01)00073-0

Document Version:

Publisher's PDF, also known as Version of record

Document license:

Taverne

Please check the document version of this publication:

- A submitted manuscript is the version of the article upon submission and before peer-review. There can be important differences between the submitted version and the official published version of record.

People interested in the research are advised to contact the author for the final version of the publication, or visit the DOI to the publisher's website.

- The final author version and the galley proof are versions of the publication after peer review.

- The final published version features the final layout of the paper including the volume, issue and page numbers.

Link to publication

\footnotetext{
General rights rights.

- You may freely distribute the URL identifying the publication in the public portal. please follow below link for the End User Agreement:

www.umlib.nl/taverne-license

Take down policy

If you believe that this document breaches copyright please contact us at:

repository@maastrichtuniversity.nl

providing details and we will investigate your claim.
}

Copyright and moral rights for the publications made accessible in the public portal are retained by the authors and/or other copyright owners and it is a condition of accessing publications that users recognise and abide by the legal requirements associated with these

- Users may download and print one copy of any publication from the public portal for the purpose of private study or research.

- You may not further distribute the material or use it for any profit-making activity or commercial gain

If the publication is distributed under the terms of Article $25 \mathrm{fa}$ of the Dutch Copyright Act, indicated by the "Taverne" license above, 


\title{
Seasonal variation in body weight: an experimental case study
}

\author{
Klaas R. Westerterp* \\ Department of Human Biology, Maastricht University, PO Box 616, 6200 MD, Maastricht, Netherlands
}

\begin{abstract}
The effect of seasonal variation in ambient temperature on body weight was studied in a man. Data were collected over three consecutive years in a temperate climate, including a two-week shift in winter to a tropical environment. A strong negative correlation existed between body weight and ambient temperature $\left(r^{2}=0.58, p<0.0001\right)$, except for the season with shift to the tropics. In the latter case, body weight dropped from 60.0 to $57.6 \mathrm{~kg}$ and remained low until summer, despite ambient temperatures down to $-4.7^{\circ} \mathrm{C}$ in late winter. In conclusion, body weight shows a clear seasonal variation triggered by ambient temperature. (C) 2001 Elsevier Science Ltd. All rights reserved.
\end{abstract}

Keywords: Body weight; Ambient temperature; Food intake; Physical activity; Thyroid activity

\section{Introduction}

Many species, including man, show an annual cycle in body weight. Potential causative factors are seasonal changes in the living environment like climate and food availability (Prentice et al., 1981). The question is whether the annual cycle still exists in our industrialized world where people live most of the day in a temperature-controlled environment and have a guaranteed and varied food supply throughout the year.

Prentice et al. (1981) showed a pronounced annual cycle of body weight in developing countries where food availability changes throughout the seasons. In Gambia, energy intake in the wet season was clearly inadequate while the dry season intake was sufficient. The study demonstrated that most adults undergo seasonal body weight changes, with weight loss during the hungry period of the wet season and weight regain during the dry season when food supplies are relatively abundant. The data, which was obtained by weighing all nonpregnant, non-lactating women of childbearing age in a rural subsistence farming community $(n=53)$, at two months intervals, showed an annual pattern of weight change with an amplitude of $1.6 \mathrm{~kg}$.

\footnotetext{
*Tel.: + 31-43-3881628; fax: +31-43-3670976

E-mail address: k.westerterp@hb.unimaas.nl
} (K.R. Westerterp).
An example of the annual cycle in body weight in the industrialized world is a study by Van Staveren et al. (1986). A random sample of 114 women in the age of 29-32 yr was selected from a small industrial town in the Netherlands. Food consumption was estimated once a month with a 24-h recall method. Subjects weighed themselves without clothes, on the day after the visit of the dietician for the 24-h recall, after the bladder had been emptied and before breakfast. Body weight showed an annual pattern with an amplitude of $0.8 \mathrm{~kg}$. It increased in the autumn and decreased in the spring. The study did not demonstrate systematic changes in energy intake throughout the year.

The latter study clearly showed that man shows an annual cycle in body weight despite an ad libitum food intake. To my knowledge, the current study is the first study on seasonal variation in body weight including measurements of ambient temperature and the effect of a shift in ambient temperature. The study presents the effects of seasonal variation in ambient temperature on body weight over three consecutive years, with ad libitum food intake, including a shift in the cold season to a tropic environment.

\section{Materials and methods}

The subject was a man, $51 \mathrm{y}$, body mass index $21.7 \mathrm{~kg} / \mathrm{m}^{2}$. Observations covered a three-year period 


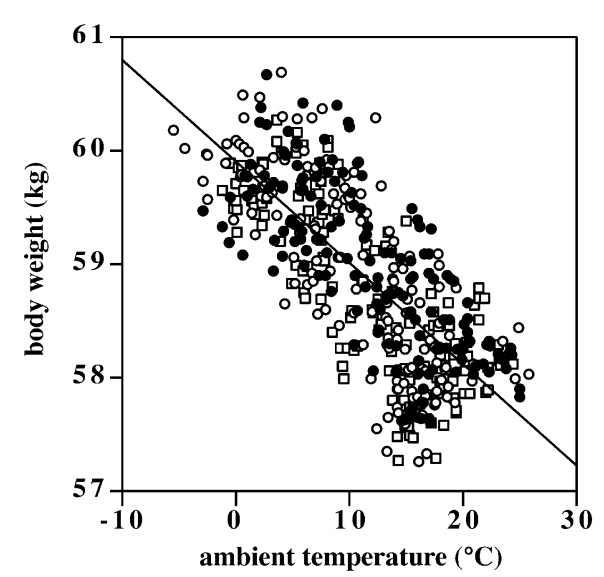

Fig. 1. Daily values of body weight plotted against the $24 \mathrm{~h}$ mean value of ambient temperature with the linear regression line; closed dots, 1997; open dots, 1998; open squares, 1999.

from July 1997 to July 2000. During the observation period, the subject resided in the Netherlands $\left(51^{\circ}\right.$ North, $6^{\circ}$ East). Once or twice a year, he went for two weeks on holiday in the summer, to an area within Europe with a similar climate. In January 1999, he went in mid-winter for two weeks to a tropical environment (Costa Rica; $9^{\circ}$ South, $84^{\circ}$ West).

Ambient temperature was taken as the $24 \mathrm{~h}$ average supplied by the Royal Dutch Meteorological Institute at a location within $10 \mathrm{~km}$ of residence. Body weight was measured daily, in the morning after emptying the bladder and before any food or water intake, on a scale accurate to $\pm 0.01 \mathrm{~kg}$ (Spider 1, Mettler Toledo, Greifensee, Switzerland).

\section{Results}

Mean daily ambient temperature ranged between a winter minimum of $-3.4^{\circ} \mathrm{C},-5.5^{\circ} \mathrm{C}$ and $-4.7^{\circ} \mathrm{C}$, and a summer maximum of $26.9^{\circ} \mathrm{C}, 25.8^{\circ} \mathrm{C}$ and $24.4^{\circ} \mathrm{C}$ over the three consecutive years. Daily values of body weight reached a winter maximum of $60.7,60.7$ and $60.3 \mathrm{~kg}$, and a summer minimum of $57.4,57.2$ and $57.3 \mathrm{~kg}$ over the same period. Apart from the season with the shift in ambient temperature, there was a strong negative correlation between body weight and ambient temperature (Fig. $1 ; r^{2}=0.58, p<0.0001$ ).

In the season with the shift from a low ambient temperature $\left(5^{\circ} \mathrm{C}\right)$ to a high ambient temperature $\left(27^{\circ} \mathrm{C}\right)$, body weight dropped from the winter value of 60.0 to $57.6 \mathrm{~kg}$ after two weeks in the tropics. Fig. 2 shows the monthly average of ambient temperature and body weight over the two complete years covered by the study, 1998 without intervention and 1999 with the shift

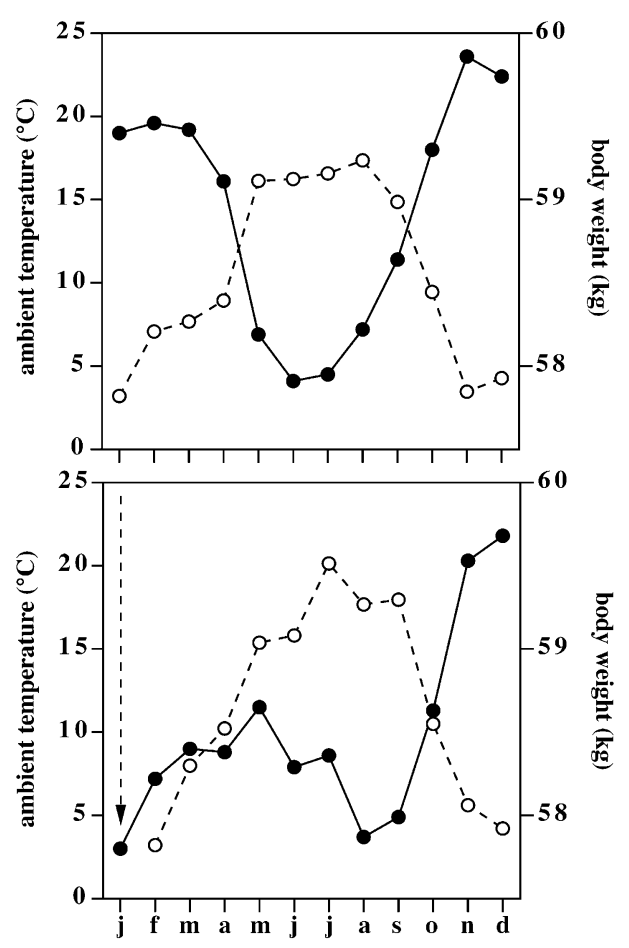

Fig. 2. Monthly values of body weight (closed dots) and ambient temperature (open dots). Upper graph: 1998; lower graph: 1999, with a two-week shift to an ambient temperature of $27^{\circ} \mathrm{C}$ (arrow).

in January for two weeks from winter temperatures to a tropical environment. For three months after the shift, body weight showed an inverse trend, increasing slowly while ambient temperature increased as well. From May onwards, the normal pattern was restored, body weight decreased again while ambient temperature increased and vice versa.

\section{Discussion}

The seasonal variation in body weight is a reflection of a systematic change in energy balance. When ambient temperature decreases after the summer, energy intake exceeds energy expenditure which results in weight gain. After winter, when ambient temperature increases, energy expenditure exceeds energy intake, resulting in the subject losing weight. Surprisingly, after a two-week exposure to a high ambient temperature in mid-winter, body weight immediately decreases to a 'summer low' and only slightly increases after return to the low winter temperature.

One of the potential mechanisms is an annual cycle in thyroid activity, triggered by daylength or ambient temperature. Thyroid volume is nearly $25 \%$ higher in 
winter than in summer (Hegedüs, 1990). Significant seasonal variations were found in both $\mathrm{T} 3$ and $\mathrm{T} 4$, where total T4 and T3 levels were highest in winter (Levine et al., 1995). Cold exposure increases serum reverse triiodothyronine, the biologically active form of T3 (McCormack et al., 1996). Animal studies suggest that the thyroid state influences food intake, in that a higher thyroid activity stimulates appetite (Rhind et al., 1998; Syed et al., 1999).

In the study by Van Staveren et al. (1986), no seasonal variation in energy intake was revealed although there was a statistically significant difference in the percentage of energy derived from fat and carbohydrates. In summer, relatively less fat and more carbohydrates were consumed. However, measurements of food intake are often prone to errors. Many studies report a difference between reported energy intake and measured energy expenditure (Goris and Westerterp, 1999). A difference $>5 \%$ is not unusual while a seasonal change in body weight of $1 \mathrm{~kg}$ can be explained by a seasonal change in energy intake of only $3 \%$ to $4 \%$. Clearly, the magnitude of seasonal changes in energy intake, which can explain the seasonal change in body weight, is close to the detection limit of dietary assessment methods.

The most likely candidate for seasonal changes in energy expenditure is physical activity. Activity-induced energy expenditure is the most variable component of our daily energy expenditure. Unfortunately, methods for the assessment of physical activity generally have an even lower resolution than dietary assessment methods. Doubly labeled water validated accelerometers for movement registration might be a potential tool for future studies (Westerterp, 1999). Additionally, a circannual rhythm of physical fitness might be a reflection of seasonal variation in physical activity (Zahorskha-Markiewicz and Markiewicz, 1984).

The amplitude of the circannual weight change in the current study was approximately $2 \mathrm{~kg}$ (Fig. 2). Of course the observation was made in a study of only one subject. On the other hand, the value is much higher than $0.8 \mathrm{~kg}$ observed by Van Staveren et al. (1986) in women in the same environment with respect to climate and food availability. The amplitude is even higher than $1.6 \mathrm{~kg}$ observed by Prentice et al. (1981) in a situation with an annual cycle of food availability. One explanation might be a gender effect. The two quoted studies (Van Staveren et al., 1986; Prentice et al., 1981) were both in women while the subject of the current study was a man. Men possibly show a more pronounced seasonal change of physical activity than women.

The current study shows that body weight shows a circannual rhythm, even with ad libitum food intake and a temperature controlled environment for most of the day. In conclusion, body weight shows a clear seasonal variation, with a minimum in summer and a maximum in winter, possibly triggered by ambient temperature and regulated by thyroid activity.

\section{References}

Goris, A.H.C., Westerterp, K.R., 1999. Underreporting of habitual food intake is explained by undereating in highly motivated lean women. J. Nutr. 129, 878-882.

Hegedüs, L., 1990. Thyroid size determined by ultrasound. Danish Med. Bul. 37, 249-263.

Levine, M., Duffy, L., Moore, D.C., Matej, L.A., 1995. Acclimation of a non-indigenous sub-Arctic population: seasonal variation in thyroid function in interior Alaska. Comp. Biochem. Physiol. 111A, 209-214.

McCormack, P.D., Reed, H.L., Thomas, J.R., Malik, M.J., 1996. Increase in rT3 serum levels observed during extended Alaskan field operations of Naval personnel. Alaska Med. 38, 89-97.

Prentice, A.M., Whitehead, R.G., Roberts, S.B., Paul, A.A., 1981. Long-term energy balance in child-bearing Gambian women. Am. J. Clin. Nutr. 34, 2790-2799.

Rhind, S.M., McMillen, S.R., Duff, E., Hirst, D., Wright, S., 1998. Seasonality of meal patterns and hormonal correlates in red deer. Physiol. Behav. 65, 295-302.

Syed, M.A., Thompson, M.P., Pachucki, J., Burmeister, L.A., 1999. The effect of thyroid hormone on size of fat depots accounts for most of the changes in leptin mRNA and serum levels in the rat. Thyroid 9, 503-512.

Van Staveren, W.A., Deurenberg, P., Burema, J., de Groot, L.C.P.G.M., Hautvast, J.G.A.J., 1986. Seasonal variation in food intake, pattern of physical activity and change in body weight in a group of young adult Dutch women consuming self-selected diets. Am. J. Clin. Nutr. 10, 133-145.

Westerterp, K.R., 1999. Assessment of physical activity level in relation to obesity: current evidence and research issues. Med. Sci. Sports Exerc. 31 (Suppl.), S522-S525.

Zahorskha-Markiewicz, B., Markiewicz, A., 1984. Circannual rhythm of exercise metabolic rate in humans. Eur. J. Appl. Physiol. 52, 328-330. 